DOI: https://doi.org/10.24867/01HZ03Micic

\title{
EVALUACIJA MOGUĆNOSTI ENERGETSKE VALORIZACIJE MULJA IZ TRETMANA KOMUNALNIH OTPADNIH VODA
}

\section{EVALUATION OF THE POSSIBILITY OF THE ENERGY VALORIZATION OF SEWAGE SLUDGE}

\author{
Jelena Mićić, Nemanja Stanisavljević, Bogdana Vujić, Fakultet tehničkih nauka, Novi Sad
}

\section{Oblast-ZAŠTITA ŽIVOTNE SREDINE}

Kratak sadržaj - Osnovna svrha master rada je da se prikaže koji od načina tretmana otpadnog mulja nastalog nakon tretmana komunalne otpadne vode bi bio najpogodniji u smislu energetske valorizacije, odnosno mogućnosti proizvodnje energije prilikom tretmana mulja. Osim toga, analizirana je i stopa recikliranja i negativan uticaj tremana mulja na životnu sredinu. Modeli su predstavljeni kao dijagrami analize tokova materijalai pored materijalnog toka (mulja) posmatrani su i tokovi supstanci (kadmijuma i ugljenika). Scenariji su izrađeni za teritoriju grada Novog Sada i nastali mulj u toku jedne godine, nakon izgradnje postrojenja za prečišćavanje otpadne vode.

Ključne riječi: komunalna otpadna voda, otpadni mulj, analiza tokova materijala, cementara, anaerobna digestija, insineracija

Abstract - The main purpose of the master thesis is to demonstrate which of the methods for treatment of sewage sludge would be most suitable in terms of energy valorization, or the possibility of energy production in the treatment of sludge. In addition, the recycling rate and the negative impact of sludge treatment on the environment were analyzed. The models were shown as diagrams of material flow analysis and in addition to the material flow (sludge), the streams of substances (cadmium and carbon) were also observed. Scenarios were made for the territory of the city of Novi Sad and the resulting generated sludge during one year, after installation of municipal wastewater treatment plant.

Keywords: municipal waste water, sewage sludge, material flow analysis, cement kiln, anaerobic digestion, incineration

\section{UVOD}

Prema podacima iz Statističkog godišnjaka, količina komunalnih otpadnih voda koja nastaje u Republici Srbiji iznosi 363,1 miliona $\mathrm{m}^{3} / \mathrm{god}$. Od ukupne količine komunalnih otpadnih voda samo $5,3 \%$ se prečišćava na odgovarajući način. Mulj koji nastaje nakon prečišćavanja otpadnih voda odlaže se na deponije, što u ovom trenutku iznosi oko 4.000 t/god. i ne predstavlja značajan pritisak [1].

\section{NAPOMENA:}

Ovaj rad proistekao je iz master rada čiji mentor je bio prof. dr Nemanja Stanisavljević.
Problem odlaganja kanalizacionog mulja u svijetu dobija na značaju, a jedan od razloga je veliki sadržaj fosfora $u$ mulju, koji može da se iskoristi kao đubrivo [2]. Međutim, otpadni mulj sadrži i neke štetne materije koje mogu dovesti do narušavanja životne sredine, ako se direktno oprimjenjuju kao đubrivo na poljoprivrednom zemljištu [3]. U nekim evropskim zemljama praksa je da se mulj nakon određenog predtretmana direktno primjenjuje kao đubrivo u poljoprivredi, ako ispunjava određene zahtjeve po pitanju sadržaja teških metala i drugih supstanci [4]. Mulj se, takođe, može koristiti i u proizvodnji cementa, zamjenjujući sirovinu za dobijanje klinkera, ili kao alternativno gorivo u procesu proizvodnje [5]. Osim toga, mogući način finalnog tretmana mulja je monoinsineracija u specijalno dizajniranim insineratorima, gdje se iz procesa insineracije može iskoristiti otpadna toplota [6]. Pošto je otpadni mulj, kao organska materija, podložan truljenju, jedan od načina krajnjeg tretmana mulja mogao bi biti i proces anaerobne digestije, u svrhu dobijanja metana [7].

Osnovni cilj rada je prikaz mogućih alternativa $u$ upravljanju otpadnim muljem nakon izgradnje postrojenja za prečišćavanje komunalne otpadne vode grada Novog Sada, prije svega sa aspekta iskorišćenja energije, a zatim i uticaja na životnu sredinu. Uz pomoć analize tokova materijala, modelovana su i analizirana tri moguća scenarija.

\section{MATERIJALI I METODE}

Osnovna podrška pri izdradi rada je softverski alat STAN, koji omogućava primjenu analize tokova materijala. Analiza tokova materijala je sistemska procjena tokova $\mathrm{i}$ zaliha materijala, $u$ određenom prostoru i vremenu i veoma je korisna metodologija pri modelovanju bilo kog materijalnog sistema [8, 9]. Modeliranje u STAN softveru sastoji se od formiranja grafičkih modela koji sadrže tokove, procese i granice sistema, nakon čega se unose podaci o masenim tokovima, koncentracijama i transfer koeficijentima, za različite nivoe (nivo dobara, nivo supstanci), odakle se na kraju izračunavaju nepoznate koncentracije i tokovi [10].

\section{REZULTATI I DISKUSIJA}

Rezultat modelovanja za potrebe izrade rada su tri moguća scenarija upravljanja otpadnim muljem, koja će biti navedena u narednim poglavljima. 


\subsection{Scenario 1}

U ovom scenariju predviđeno je da se sirovi mulj šalje na predtretman, odakle se dobija mulj koji se može koristiti u cementari. Predtretman u ovom slučaju podrazumijeva sušenje muljnim lagunama na suncu. Ovaj način predtretmana može se smatrati ekonomski najisplativijim jer ne zahtjeva dodatnu potrošnju energije. Prije predtretmana sadržaj suve materije u mulju iznosi oko $4.2 \%$, da bi se sušenjem postiglo da sadržaj suve materije bude 24\% SM [2]. Mulj se zatim može koristiti u cementari, direktnim sagorijevanjem u rotacionoj peći. Nakon spaljivanja u rotacionoj peći, čvrst ostatak $u$ vidu pepela se ne javlja, međutim veći dio sagorjele količine mulja zavšava u toku otpadnog gasa. MFA transfer koeficijenti prema doktorskoj disertaciji N. Stanisavljevića su: 0.294 za dio mulja koji odlazi u klinker i 0.706 za dio mulja u otpadnom gasu. Na slici 1 . prikazan je MFA dijagram tokova mulja, na nivou dobara, u Scenariju 1.

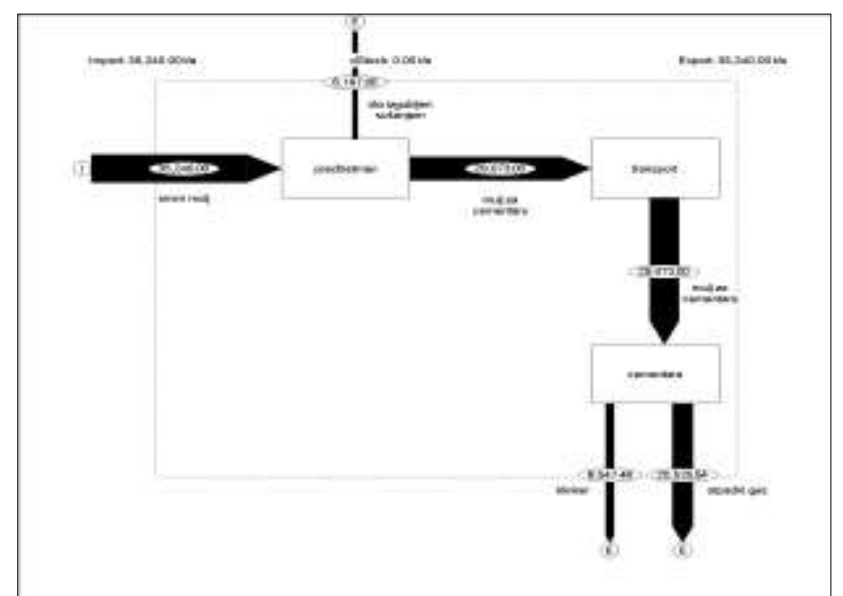

Slika 1. MFA dijagram tokova mulja za Scenario 1

Kada posmatramo tokove ugljenika kroz otpadni mulj koji se sagorijeva u cementari, količina ugljenika kojom se raspolaže izračunata je na osnovu koncentracije ugljenika. Koncentracija ugljenika posle sušenja na suncu iznosi oko $286 \mathrm{mg} \mathrm{C/g}$ mulja,a procijenjeno je da nakon sušenja 95\% ugljenika ostane u mulju, dok 5\% ispari sušenjem [12].

Ubacivši datu koncentraciju MFA dijagram, nakon kalkulacije dobijena je količina od 8752.5 t/godišnje ugljenika. U poređenju sa sličnim MFA analizama zaključeno je da je vrijednost dobijenog ugljenika $u$ realnim okvirima. Situacija sa ugljenikom prilikom sagorijevanja mulja u cementari je slična kao kod analize na nivou dobara. Dakle, veći dio ugljenika završava u otpadnom gasu, što je posledica sagorijevanja jer se ugljenik pretvara u gasovite produkte kao što je ugljendioksid. Korišćeni transfer koeficijenti prema doktorskoj disertaciji N. Stanisavljevića su: 0.01 za tok klinker i 0.99 za tok otpadni gas.

Kod tokova kadmijuma, u proračun je uzeta prosječna koncentracija kadmijuma u sirovom mulju za Njemačku i odabrane evropske zemlje i iznosi $5 \mathrm{mg} \mathrm{Cd} / \mathrm{kg}$ suve materije [2]. Za količinu sirovog mulja od $35240 \mathrm{t}$ (sadržaja suve materije $4.2 \%$ i izračunate količine suve materije od 1480,08 t) izračunata je količina kadmijuma i iznosi $7.4 \mathrm{~kg} \mathrm{Cd}$ /godišnje.

Transfer koeficijenti za predtretman kadmijuma su usvojeni na osnovu činjenice da kadmijum ima svojstvo vezivanja za neisparljive komponente mulja i iznose $2 \%$ za dio izgubljen sušenjem i $98 \%$ za mulj koji ide u cementaru. Transfer koeficijenti za tokove kadmijuma tokom spaljivanja u cementari su: 0.02 za otpadni gas i 0.98 za klinker [13].

\subsection{Scenario 2}

$\mathrm{Za}$ Scenario 2. koji se odnosi na tretman mulja u anaerobnom digestoru, prije svega razmatrano je da li je potreban predtretman mulja prije slanja $\mathrm{u}$ anaerobni digestor. Ako je jednostepena digestija (što je slučaj u ovom scenariju) mulj sa 3-5\% suve materije ne mora na predtretman. Prethodno je utvrđeno da je sadržaj suve materije u mulju nakon tretmana komunalnih otpadnih voda $4.2 \%$, pa je predtretman izuzet iz razmatranja.

U ovom scenariju mulj sadržaja suve materije $4.2 \%$ šalje se direktno u digestor, gdje se pod dejstvom anaerobnih bakterija vrši anaerobna razgradnja organske materije. Produkti anaerobne razgradnje su proizvedeni gas i ostatak mulja koji se naziva digestat. Transfer koeficijenti koji su korišćeni na nivou dobara su 0.15 za proizveden gas i 0.85 za digestat [7]. Proizveden gas je u slučaju anaerobne digestije od $40-60 \%$ metan, pa se može iskoristiti u energetske svrhe. Za digestat je uzeta u obzir opcija da se koristi kao kompost. U ovom slučaju predtretman je zahtjevan, pa je razmatrana mehanička dehidratacija mulja, odakle će izlazni tokovi biti frakcija za kompostiranje i otpadna voda.

Kada se posmatraju tokovi ugljenika, pošto sirovi mulj ne ide na predtretman, količina ugljenika prisutna u mulju je nešto veća nego kod Scenarija 1. Nakon digestije 33\% količine mulja odlazi u proizveden gas, a $67 \%$ ide na predtretman za kompostiranje [7].

Kadmijum nakon procesa anaerobne digestije $96 \%$ je sadržan u digestatu, dok je $4 \%$ sadržan u proizvedenom gasu, a nakon predtretmana za kompostiranje većina kadmijuma je u frakciji za kompostiranje, što je sa stanovišta zaštite životne sredine problem ukoliko koncentracija kadmijuma prelazi granične vrijednosti emisije. Na slici 2. prikazan je dijagram tokova mulja na nivou dobara, za Scenario 2

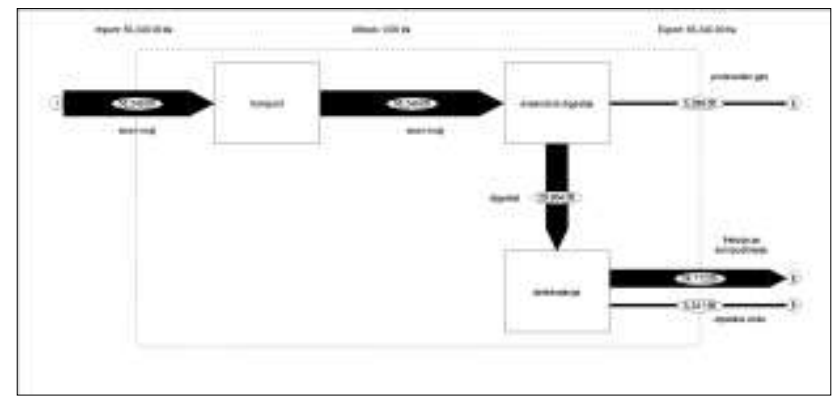

Slika 2. MFA dijagram tokova mulja za Scenario 2

\subsection{Scenario 3}

Za ovaj scenario razmatrano je da se mulj nakon predtretmana (sušenja na suncu) transportuje do insineratora, gdje će se vršiti njegov termički tretman, 
odnosno spaljivanje. Direktni izlazi iz procesa sagorijevanja uključuju pepeo sa dna, leteći pepeo i otpadni gas. Otpadni gas se tretira prije ispuštanja u atmosferu, a nakon tretmana ostaju otpadne vode i filterski kolač. Filterski kolač se zajedno sa letećim pepelom deponuje na posebnoj deponiji, zbog sadržaja opasnih materija, a pepeo sa dna se odlaže na sanitarnu deponiju. Transfer koeficijenti su usvojeni na osnovu [12] i prikazani su u tabeli 1 .

Tabela 1. Usvojeni transfer koeficijenti [12]

\begin{tabular}{|c|c|c|c|c|c|c|c|}
\hline \multirow{2}{*}{$\begin{array}{c}\text { Produk } \\
\mathbf{t}\end{array}$} & \multirow{2}{*}{$\begin{array}{c}\text { Maseni } \\
\text { udeo }\end{array}$} & \multicolumn{6}{|c|}{ Supstance } \\
\cline { 3 - 8 } & $\mathrm{C}$ & $\mathrm{N}$ & $\mathrm{Cl}$ & $\mathrm{Cd}$ & $\mathrm{Pb}$ & $\mathrm{Hg}$ \\
\hline $\begin{array}{c}\text { Leteći } \\
\text { pepeo }\end{array}$ & 0.025 & 0.002 & 0 & 0.37 & $\begin{array}{c}0.91 \\
6\end{array}$ & 0.25 & 0.5 \\
\hline $\begin{array}{c}\text { Pepeo } \\
\text { sa dna }\end{array}$ & 0.27 & 0.014 & 0.01 & 0.09 & 0.08 & 0.75 & 0.04 \\
\hline $\begin{array}{c}\text { Otpadni } \\
\text { gasovi }\end{array}$ & 0.7 & 0.98 & $\begin{array}{c}0.98 \\
9\end{array}$ & $\begin{array}{c}0.00 \\
01\end{array}$ & $\begin{array}{c}0.00 \\
2\end{array}$ & $\begin{array}{c}0.000 \\
2\end{array}$ & 0.02 \\
\hline $\begin{array}{c}\text { Otpadn } \\
\text { e vode }\end{array}$ & $\begin{array}{c}<0.01 \\
(0.0001 \\
)\end{array}$ & 0.002 & $\begin{array}{c}0.00 \\
1\end{array}$ & 0.54 & $\begin{array}{c}0.00 \\
1\end{array}$ & 0.001 & 0.00 \\
1
\end{tabular}

Sa aspekta tokova dobara (materijala) najveća količina mulja nakon insineracije je sadržana u otpadnim gasovima. To je rezultat oksidacije organskih materija iz mulja. Pepeo sa dna sadrži 27\% količine mulja. Ostatak je sadržan u letećem pepelu i produktima prečišćavanja otpadnih gasova (filterski kolač i otpadne vode). Za prečišćavanje otpadnih gasova vršena je apsorpcija gasovitih polutanata $u$ tečnost. Na slici 3. prikazan je dijagram tokova mulja na nivou dobara, za Scenario 3.

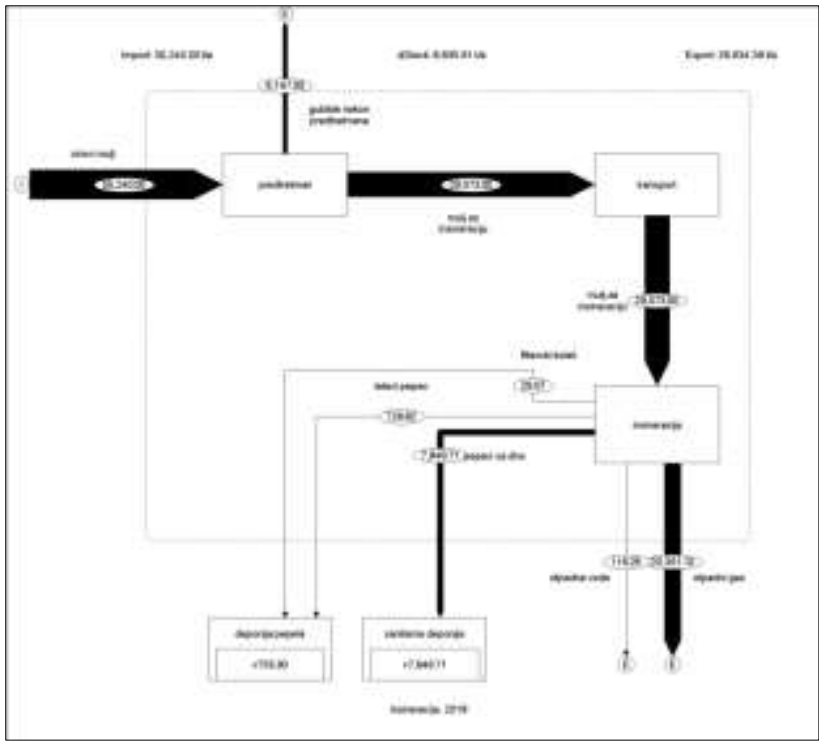

Slika 3. MFA dijagram tokova mulja za Scenario 3

\subsection{Analiza scenarija sa energetskog aspekta}

Ako bi se za kapacitete grada Novog Sada izgradilo postrojenje za prečišćavanje otpadnih voda, proračunom je dobijeno da bi u tom slučaju nastala količina mulja od 35240 t/god. Za Scenario 1 - spaljivanje mulja u cementari, predviđeno je da se sva količina mulja nakon predtretmana (sušenja na suncu) spaljuje u rotacionoj peći. Količina mulja nakon sušenja iznosila bi 29073 t/godišnje. Prethodnim radovima na sličnu temu proračunato je da je kapacitet cementare Lafarge, koja se nalazi nedaleko od Novog Sada, 1004000 t/god, a da je maksimalna upotreba otpadnog mulja $50200 \mathrm{t} / \mathrm{god}$, što znači da bi se nastala količina mulja nakon predtretmana mogla zbrinuti u navedenoj cemetari [14]. Pošto bi se u tom slučaju mulj koristio kao zamjena za ugalj, sa aspekta potrošnje energije to bi bio pozitivan korak.

U proračun ćemo uzeti toplotnu vrijednost mulja od 18 $\mathrm{MJ} / \mathrm{kg}$, odnosno $18 \mathrm{GJ} / \mathrm{t}$, tada bi proizvedena količina energije iznosila:

$18 \mathrm{GJ} / \mathrm{t} * 35240 \mathrm{t} / \operatorname{god}=634320 \mathrm{GJ} / \mathrm{god}$

Ako se usvoji toplotna vrijednost uglja, koji se koristi kao energent u cementari, od $27 \mathrm{GJ} / \mathrm{t}$, može se izračunati koju količinu uglja može da zamijeni mulj.

$634320 \mathrm{GJ} /$ god : $27 \mathrm{GJ} / \mathrm{t}=23493 \mathrm{t}$ uglja/godišnje

Za Scenario 2 posmatraćemo količinu proizvedenog gasa koji nastaje prilikom anaerobne digestije. Od ukupne količine mulja, prema transfer koeficijentima 33\% odlazi u proizveden gas. Pošto je u sastavu biogasa od 50-70\% metan $\left(\mathrm{CH}_{4}\right)$ za potrebe proračuna usvojiće se da je sadržaj metana $65 \%$. Toplotna moć biogasa zavisi od sadržaja metana, za sadržaj metana od $65 \%$ toplotna moć se kreće u opsegu od 16,2-19,8MJ/ $\mathrm{Nm}^{3}$. Oko 18.31 biogasa se, u prosjeku, generiše dnevno po glavi stanovnika, ako se posmatra postrojenje koje ima tehnički potencijal da preradi kanalizacioni mulj dobijen od 50.000 stanovnika [15]. Za Novi Sad ta količina biogasa, prema broju od 319484 stanovnika, iznosi:

$18,3 \mathrm{l} / \mathrm{dn} / \mathrm{st} * 319484 \mathrm{st}=5846557,2 \mathrm{l} / \mathrm{dan}=$ $=5846,6 \mathrm{~m}^{3} / \mathrm{dan}=2134009 \mathrm{~m}^{3} / \mathrm{god}$.

Ako se usvoji toplotna moć biogasa od $17 \mathrm{MJ} / \mathrm{Nm}^{3}$ može se dobiti moguća proizvedena energija i iznosi 36278153 $\mathrm{MJ} / \mathrm{god}=36278 \mathrm{GJ} /$ godišnje.

Kod Scenarija 3 uzeće se u obzir količina toplote (energije) koja nastaje spaljivanjem mulja. Ta količina toplote ekvivalenta je količini nastaloj spaljivanjem mulja u cementari i iznosi 634320 GJ/god. Prilikom insineracije energija se može koristiti na različite načine kao što su proizvodnja tople vode ili proizvodnja električne energije.

Tabela 2. Moguća proizvedena energija prema scenarijima

\begin{tabular}{|l|l|l|l|}
\hline & Scenario 1 & Scenario 2 & Scenario 3 \\
\hline $\begin{array}{l}\text { Proizvedena } \\
\text { energija } \\
\text { (GJ/god) }\end{array}$ & 64320 & 36278 & 64320 \\
\hline
\end{tabular}

\section{ZAKLJUČAK}

Istraživanje na kom se bazira master rad ogleda se u definisanju modela za tretman i dispoziciju otpadnog mulja nastalog nakon prečišćavanja komunalne otpadne vode na teritoriji Novog Sada.

Kako je prethodno već naglašeno, definisani modeli su predviđeni za budući period u razvoju Novog Sada, i to nakon izgradnje postrojenja za prečišćavanje komunalne otpadne vode. U trenutnom statusu sva kanalizaciona otpadna voda se ispušta u rijeku Dunav bez prečišćavanja, dakle ne postoje zalihe mulja koje bi se mogle tretirati. Stoga su iste proračunate na osnovu različitih parametara $i$ 
za period od jedne godine bi iznosile oko $35.240 \mathrm{t}$ za teritoriju opštine Novi Sad.

Modeli tretmana otpadnog mulja su definisani kroz tri scenarija. Prvi scenario podrazumijeva tretman mulja u peći cementara. Na taj način, mulj određenog sadržaja suve materije se spaljuje u peći, nakon čega se kao produkt dobija otpadni gas i čvrsti ostatak, koji je ugrađen u sirovinu za dobijanje cementa (klinker).

Drugi scenario se odnosi na tretman mulja u anaerobnom digestoru, gdje se mulj pod dejstvom anaerobnih bakterija razlaže na gasovite i čvrste produkte. Gasoviti produkti su metan i ostali gasovi, dok je čvrsti ostatak izreagovani mulj koji se može koristiti kao sirovina za kompostiranje, nakon predtretmana, odnosno isušivanja viška vlage.

Treći scenario se, takođe, kao i prvi odnosi na spaljivanje komunalnog otpadnog mulja, ali ovaj put u specijalno izgrađenim insineratorima koji služe za spaljivanje otpada. Kao produkti dobijaju se otpadni gas, pepeo sa dna i leteći pepeo. Za otpadni gas je predviđeno prečišćavanje vlažnim postupkom, pa je nakon toga dodatni nusprodukt otpadna voda.

Kod svih navedenih scenarija, analizom tokova materijala (uz korišćenje definisanih transfer koeficijenata) praćeni su tokovi materijala (otpadnog mulja), kao i supstanci (kadmijuma i ugljenika). U radu su prikazani neki od grafičkih modela scenarija na kojima su predstavljeni pomenuti tokovi, kao i procesi koji se dešavaju prilikom određenih tretmana otpadnog mulja.

Kod energetske analize scenarija, za Scenario 1 i Scenario 3 od značaja je bila toplotna moć mulja, pa su stoga dobijene vrijednosti moguće proizvedene energije jednake, jer se spaljuju iste količine mulja. U prvom scenariju mulj bi se koristio kao zamjena za ugalj, a u trećem bi se mogla iskoristiti proizvedena otpadna toplota nakon sagorijevanja mulja u insineratoru. Kod Scenarija 2, energija bi se mogla proizvoditi od dobijenog biogasa $i$ u tom slučaju dobila bi se skoro upola manja količina energije, nego kod spaljivanja u cementari i insineratoru. Sagledavajući prethodno navedene analize Scenario 1 iskorišćenje mulja u cementnoj industriji bi mogao biti favorizujući model. Još jedan razlog koji doprinosi tome je to što u okolini Novog Sada već postoji izgrađena fabrika cementa koja ima potrebne kapacitete da zbrine nastalu količinu mulja. Upotrebom mulja u cementari bi mogla da se zamijeni znatna količina uglja, a sa aspekta zaštite životne sredine ovaj način tretmana mulja je pogodan jer nema čvrstih otpadnih produkata pošto se sav nastali pepeo ugrađuje u klinker.

\section{LITERATURA}

[1] Republika Srbija, Republički zavod za statistiku, 2017. Otpadne vode naselja 2016., Statistika životne sredine

[2] Lederer J, Rechberger H. 2010. Comparative goal-oriented assessment of conventional and alternative sewage sludge treatment options, Waste Management 30 (2010) 1043-1056

[3] B.Fjaalborg, G.Dave, Toxicity of $\mathrm{Sb}$ and $\mathrm{Cu}$ in Sewage sludge to Terrestrial Plants (Lettuce, Oat, Radish), and of Sludge Elutriate to Aquatic Organisms (Daphnia and Lemna), and its Interraction, Water, Air and Soil Pollution, 2004. Vol.155 (1), pp. 3-20.

[4] Andersen A., 2001. Disposal and Recycling Routes for Sewage sludge: Part 3 - Scientific and Technical Report. European commision, DG Environmen, Brussels, Belgium
[5] Simić S, Stanojević M. 2017. Razmatranje mogućnosti upotrebe otpadnog mulja u industriji cementaZbornik Međunarodnog kongresa o procesnoj industriji - Procesing, [S.1.], v. 23, n. 1

[6] Tomić R. 2014. Druge metode strabilizacije muljeva i obezvodnjavanje, Water workshop, Departman za hemiju, biohemiju i zaštitu životne sredine, Prirodno-matematički fakultet, Novi Sad

[7] Knoop C, Tietze M, Dornack C, Raab T. 2018. Fate of nutrients and heavy metals during two-stage digestion and aerobic post-treatment of municipal organic waste,

Bioresource technology 251 (2018) 238-248

[8] Brunner P.H., (2004), Materials Flow Analysis and the Ultimate Sink

[9] Brunner\&Rechberger, 2005. Practical handbook of Material Flow Analysis, ISBN 1-5667-0604-1

[10] Stanisavljević N., Brunner P.H. 2014. Combination of material flow analysis and substance flow analysis: A powerful approach for decision support in waste management, Waste Management \& Research, Vol 32 (8) 733-744

[11] Indra V, Sivaji S. 2006. Metals and organic components in sewage sludge, Journals of environmental biology, 27 (4) 723 725

[12] Stanisavljević N. 2013. Modelovanje sistema za upravljanje otpadom primenom analize tokova materijala. Doktorska disertacija, Fakultet tehnickih nauka, Novi Sad

[13] Kalinić T. 2017. Evaluacija kapaciteta zbrinjavanja komunalnog otpadnog mulja u cementarama u Srbiji, Master rad, Fakultet tehničkih nauka, Novi Sad

[14] Deublein D, Steinhauser A. 2008. Biogas iz otpada i obnovljivih izvora, preveli: Ervin i Nataša Salma

\section{Kratka biografija:}

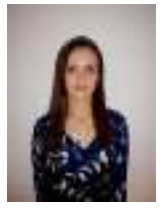

Jelena Mićić rođena $\mathrm{u}$ Vlasenici, $\mathrm{BiH}$, 1993.godine. Master rad na Fakultetu tehničkih nauka iz oblasti Inženjerstvo zaštite životne sredine - Analiza tokova materijala, odbranila je 2018.god. kontakt: jelenamicic93@gmail.com

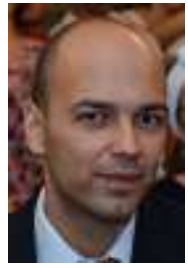

Nemanja Stanisavljević, vanredni profesor na Fakultetu tehničkih nauka, doktorirao je 2013. na Fakultetu tehničkih nauka u Novom Sadu. Postdoktorsko usavršavanje je relizovao kao Fulbrajtov stipendista u SAD-u, na Državnom Univerzitetu Severne Karoline, Departmanu za mašinstvo, građevinu i inženjerstvo zaštite životne sredine. Od 2015. godine izvodi nastavu kao gostujući profesor na Tehničkom Univerzitetu u Beču, Austriji.

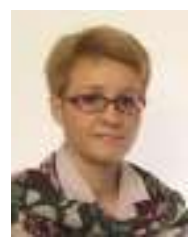

Bogdana Vujić, vanredni profesor na Tehničkom fakultetu „Mihajlo Pupin“ U Zrenjaninu, doktorirala je 2010. na Fakultetu tehničkih nauka u Novom Sadu. Do 2012. godine, bila je zaposlena u Pokrajinskom sekretarijatu za zaštitu životne sredine i održivi razvoj. 